\title{
Leader responsibility in the workplace: Exploring the shepherd metaphor in the book of Jeremiah
}

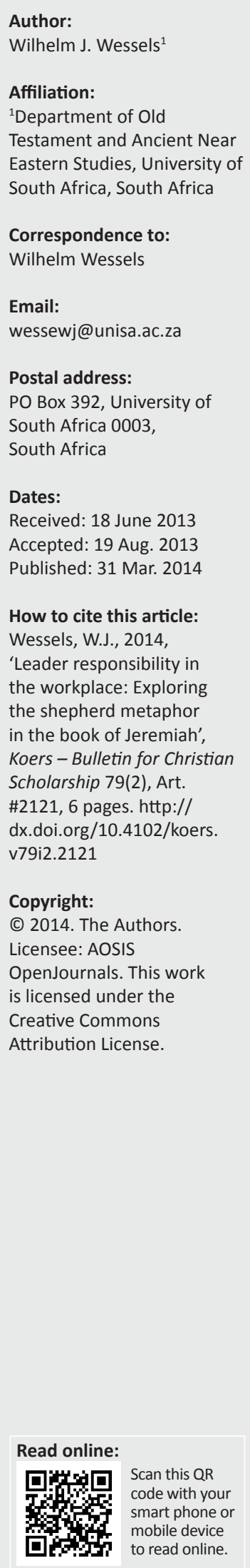

Leadership and responsibility go hand in hand in the workplace. Secular literature has explored this aspect in great length and has emphasised the various aspects this characteristic of leadership entails. In this article I briefly refer to some of the areas and aspects of responsibility that come the way of leaders in the workplace. However, this article aims at making a contribution from a biblical perspective, more particularly by exploring some aspects of the shepherd metaphor in the book of Jeremiah. From looking into this metaphor there are three aspects of leadership which emerge that I wish to address, namely: to lead people, to care for people and the less obvious third aspect of exercising justice and righteousness. Not only are leaders responsible for exercising justice and righteousness in the area of their leadership; they also have to see that justice and righteousness prevail and are safeguarded in settings where they have leadership responsibilities. The aim of this article, finally, is to relate these insights which emerged from the investigation of the shepherd metaphor in the book of Jeremiah to the context(s) of the modern-day workplace.

Verantwoordelike leierskap in die werkplek: 'n Ondersoek na die herdermetafoor in die Jeremiaboek. Leierskap en verantwoordelikheid gaan hand aan hand in die werkplek. Hierdie aspek is in detail ondersoek in die sekulêre literatuur en baie van die kenmerke van leierskap is al beklemtoon. In hierdie artikel word verwys na areas en aspekte van belang wat leierskap in die werkplek raak. Die doel van die artikel is egter om vanuit 'n Bybelse perspektief ' $n$ bydrae te maak deur'n ondersoek te doen na die gebruik van die herdermetafoor in die boek Jeremia. Ek wil drie aspekte in die verband uitlig: om mense te lei, om na mense om te sien en 'n derde minder voor die hand liggende aspek, om reg en geregtigheid te laat geskied. Dit is leiers se verantwoordelikheid om self reg en geregtigheid toe te pas, maar ook om toe te sien dat reg en geregtigheid geskied in die plekke waar hulle die verantwoordelike leiers is. 'n Laaste oogmerk met hierdie artikel is om die kennis wat verwerf is deur die navorsing in Jeremia relevant te probeer maak vir die werkplek vandag.

\section{Introduction}

Nobody will dispute the fact that leaders have a responsibility in the workplace in terms of ethics, but also for the well-being of employees (Dewe \& Cooper 2012:41-44, 163-164; DuBrin 2013:153-155, 160). The particular aim of this article is to present views on Christian leaders in the workplace. The type of leadership defined here is Christian leadership, which means that a very specific take on leadership is focused on. The approach in this article is to look at leadership from an Old Testament perspective, seeing that the Old Testament is also part of the book Christians regard as their canon.

There are many definitions of leadership, all of them contributing a perspective on the multi-faceted phenomenon we call leadership. A definition which seems to fit the particular view of leadership this article wants to contribute to, namely Christian leadership, is formulated by Ciulla (2004:xv): 'Leadership in not a person or a position. It is a complex moral relationship between people, based on trust, obligation, commitment, emotion, and a shared vision of the good.' Christian leadership is all about the ethical component in society that cares for relationships between people because of their relationship with God. The view taken in this article is that a discussion of the shepherd metaphor in the book of Jeremiah will not only enrich our understanding of the relational component of leadership in society, but will challenge right-minded people to consider seriously the ethical emphasis of Jeremiah's shepherd-leadership requirements. The discussion offered in this article will tie in with the leadership definition of Ciulla presented above. Not only will the functional aspect of leadership be addressed in the discussion of the shepherd metaphor; the moral aspect of leadership will receive special emphasis.

The aim of this article is to show that the shepherd metaphor, as it is used in the book of Jeremiah, highlights key aspects essential for deliberation on leadership in governmental and workplace 
structures. To achieve this aim, first, metaphor theory will briefly be addressed, followed by an exposition of passages in Jeremiah in which the shepherd metaphor occur. This is followed by a discussion that is introduced on moving from the text to the reality of exercising leadership that exhibits Christian principles.

\section{Metaphors}

A metaphor is a stylistic device applied to understand or describe one thing in terms of another. The two components or elements compared are from different conceptual domains. In a metaphor the link made between the two components is direct (e.g. men are pigs). When the connection between the two components is less direct (e.g. men are like pigs), the type of metaphor is called a simile (Jindo 2010:xiii-xv). I will use the term 'metaphor' in the generic sense of the word. O'Brien (2008:xvi-xvii) argues that metaphors are strategically important tools prophets use to persuade their audiences. Metaphors create mental pictures that involve people who hear or read them, with a view to getting them to respond.

In the Jeremiah text the metaphor of a shepherd is used to refer to the leaders in the Judean society (Jr 3:15; 6:3; 10:21; $12: 10 ; 22: 22 ; 23: 1 ; 23: 4 ; 25: 34-36)$. The concept of a shepherd comes from the domain of rustic life where a person is given the responsibility to lead sheep into pastures, to watch over them, to keep them together, to protect them and to bring them back to safety. It is not too difficult to have a mental picture of a shepherd tending the flock. The comparison is drawn with that of leaders in a society from the domain of leadership structures in government and affiliated institutions. The purpose of using the shepherd metaphor is to incite the imagination of the people to think of leaders in terms of what they know shepherds do: shepherds lead, care, feed and protect their flock. The shepherd metaphor also clearly indicates where the responsibility lies in the relationship between the shepherd and the flock. The focus in this comparison is therefore squarely placed on the shoulders of the leaders in society.

In this article the shepherd metaphor is explored for the purpose it served and for the appeal it makes in terms of Christian leadership in all spheres of life.

\section{The shepherd metaphor in the book of Jeremiah}

The use of the shepherd metaphor to refer to leaders is not new in the literature of the Bible (Ez 34:2, 7; Mi 5:4). This is not strange, considering the nature of the societal life which had a strong rustic background. The literal use of the term 'shepherd' was part of everyday life in terms of people tending a flock. In this regard the care for the sheep was the primary duty of the shepherd, leading the sheep to the pastures and safeguarding the animals against any kinds of threat. The figurative meaning of the term 'shepherd' to refer to leaders is a natural application of the concept, taking into account the nomadic background of the people of Israel.
Moses was a leader in the mould of a shepherd and David is associated par excellence with a rural background and the idea of a shepherd king. His calling and anointing by Samuel to be the future king of Israel is displayed against the setting of David as a shepherd boy elected to become the shepherd of people.

But, as mentioned before, the interest of this article lies in Jeremiah's use of the concept shepherd to refer to the leaders in his society. The primary focus for the discussion is Jeremiah 23:1-6. I will, however, also refer to other instances in the book of Jeremiah where the word 'shepherd' is used to take issue with leaders in society.

\section{Jeremiah 23:1-6}

Jeremiah 23:1-6 consists of two sections, namely verses 1-4 and verses 5-6. Verses 1-4 are in prose style (Rudolph 1968:145-146; cf., however, Thompson 1980:485-486, who differs), whereas verses 5-6 are poetic in nature (Carroll 1986:446). Jeremiah $23: 1-2$ is a prophetic judgement oracle introduced by an exclamation of woe, followed by the indictment. Verse 2 announces the outcome of this indictment. It is introduced by the word 'therefore' followed by the verdict that $\mathrm{YHWH}$ will intercede and execute his judgement (Fretheim 2002:324). YHWH's involvement, however, will not entail judgement alone, but verse 3 and verse 4 announce how he will act to rectify the situation to the benefit of the people of Judah and Israel (Brueggemann 1998:205-206). The next two verses (23:5-6) continue to spell out how YHWH will change a woeful situation into one that will be favourable to the people.

The relevance of this section in the book of Jeremiah is the target of the judgement, namely the shepherds. These shepherds are blamed for not performing as they were supposed to by taking care of their sheep. Instead, the verdict is that they have destroyed and scattered the sheep belonging to $\mathrm{YHWH}$. The indictment includes the following: you have destroyed the people, you have scattered my flock, you have driven them away and you have not attended to them ( $p q d)$. The images used here are those of a shepherd and a flock. It is quite obvious that the leaders (shepherds) referred to here are people governing over the people of Judah and Israel, the flock. The verbs appearing here are negative words, but they express clearly what these leaders were supposed to do, but are not doing. It was expected of shepherds to care for the safety of the flock, yet instead they are blamed for destroying it. The shepherds (leaders) were supposed to keep the flock together in order for them to be safe and accounted for; instead, they are blamed for scattering the people. Furthermore, they were expected to gather the flock of sheep; instead, they are blamed for driving them away. It was expected of shepherds to be with their flock and bestow care on them ( $p q d)$, yet they neglected to care for the flock. For these various forms of neglect, labelled as 'evil doings', YHWH will punish (pqd)

1.For detailed discussions of these verses, see the commentaries of Carroli (1986:443447), McKane (1986:491-567), Fischer (2005:676-681) and Allen (2008:255-260). For insightful comments on the literary detail of Jeremiah 23:1-6, the commentary of Lundbom (2004:164-176) is a good source to consult. 
the shepherds (leaders; for highlighting the wordplay on $p q d$, see Craigie, Page \& Drinkard 1991:325). The verb used here literally means 'to visit' the people. When YHWH does the visiting, it is generally for negative reasons of punishment (Sweeney 2007:313-314).

The references in these two verses are vague unless placed in a concrete historical context in the southern part of Palestine, which housed the people of Judah. These verses are uttered against the background of a specific period in the history of Judah, the Southern Kingdom. Jeremiah was a prophet who acted in the last years before the commencement of the Babylonian exile. At that stage in history the Babylonians replaced the Assyrians as the world dominating power and threatened for many years to invade Judah and more particularly Jerusalem as the seat of power. The people of Judah were taken into exile to Babylon on several occasions, of which the main dates were $597 \mathrm{BCE}$ and $586 \mathrm{BCE}$. The verbs such as scatter and driven away we come across in verse 1 and verse 2 are therefore references to the exile of the people of Judah due to the neglect of their leaders to take care of their people. The people of Judah suffered the consequences of the failed leadership, which resulted in their exile from their homeland. The exile was YHWH's punishment.

This knowledge and background material will contribute to the understanding first of 23:3-4, but also of 23:5-6. At the end of verse 2 the first person singular appears as the acting party and that continues in the next several verses as well. The ' $I$ ' referred to is $\mathrm{YHWH}$, who intercedes and takes control of the turnaround process. The leaders (shepherds) have failed the flock and for that reason YHWH will attend to them in the negative sense of the word by punishing them. However, in verse 3 YHWH states that circumstances are about to change because he will take control of matters. Jeremiah 23:3-4 can be regarded as a proclamation of salvation (Allen 2008:257258). The action YHWH will take will be a reverse of what took place under the failed leadership of the 'shepherds' of Judah. According to verse 3, YHWH will gather the people who have survived the exile (called a 'remnant'). He caused the exile by using foreign nations as a means of punishing the people - the Assyrians as far as Israel, the Northern Kingdom, are concerned and the Babylonians in the case of Judah. On their return to their country, the Judean returnees will be blessed in the sense that they will be fruitful and multiply. Verse 4 returns to the idea of shepherds as leaders, but this time YHWH will appoint the new shepherds (leaders). The implication of YHWH appointing the new leadership has the far-reaching implications that the leadership from the lineage of David will not continue as in the past. The idea of a dynasty and the obvious succession of the next leaders will no longer be the natural order of things. The new leadership will restore trust in them as leaders, with the result that fear will subside and people will feel safe again. More than that, these new leaders will displace feelings of dismay and anxiousness and create a sense of faith and hope. The leaders will also be accountable for their followers; they will ensure that nobody will be missing or go missing.
The next two verses (23:5-6) are in poetic style and therefore different from the previous four prose verses. Some people argue that Jeremiah 23:5-6 is a later addition to verses 1-4 (cf. Lundbom 2004:171 for a discussion of the various views on this issue). Whatever the case may be, it now forms part of the unit 23:1-6 in the Masoretic text and adds an essential component to the discussion on the shepherd leaders. Jeremiah 23:5-6 qualifies shepherd leadership in terms of justice and righteousness.

There is a change in person from plural in verses $1-4$ to a singular subject in verse verses 5-6. The last two verses form a salvation prophecy, indicating what $\mathrm{YHWH}$ is planning for the people of Israel and Judah in the near future. Allen (2008:258) refers to verses 5-6 as 'a royal proclamation of salvation'. Whereas reference was made in verses 1-4 to leaders in the plural, in 23:5-6 a single person is referred to, a descendent of David. The future leader will therefore be a king and the rule of this king will be righteous. What is very important for this article is that this leader of the government and the people will act with wisdom as a first qualifier of his governing. To this is added that this leader will do what is just and right in the land.

Jeremiah 23:1-6 should not be seen in isolation; it is part of the bigger unit commencing in Jeremiah 21:1. This bigger unit consists of several oracles on the kings in the last days before the Babylonians invaded Jerusalem and took the inhabitants into exile. The common theme of this cycle of oracles is failed leadership. The reference to the leaders in 23:1-4 as shepherds is a reference to the government leaders, consisting of the kings and their administrators. From the discussion above, several aspects of failure were pointed out that are well defined by the use of the shepherd metaphor. However, the addition of 23:5-6 also brings the aspects of justice and righteousness into play. The leader $\mathrm{YHWH}$ will raise will excel in doing what is just and what is fair. This refers back to the section in the cycle on failed leadership to the conduct of King Jehoiakim. This link was already noticed by Craigie et al. (1991:325). Lundbom (2004:170) also links this passage to the oracle against King Jehoiakim and indicates that this oracle also commences with a 'woe' exclamation. In Jeremiah 22:13-19 the abuse of this leader's actions is described. Firstly it is stated that his actions show contempt for justice (mišpa $\bar{t}$ ). ${ }^{2}$ This is explained by highlighting Jehoiakim's desire to be like an Egyptian despot. He has embarked on an elaborate palace building project to strengthen his position of power and to enrich himself. He had no concern for the law and forced people to work on his building project without payment. Besides that, his extravagant building project could be seen as the misuse of state funds to satisfy his personal interests. An even more serious allegation was that it was done at the cost of people's lives. The use of forced labour resulted in the blood of ordinary workers being spilled for personal gain.

2.In Jeremiah we find two words that relate to matters of justice and righteousness, namely mišp $\bar{a} t$ and $s^{e} d \bar{a} q \bar{a}$. These two words are often used in combination, but at times their use is indistinguishable. It seems that these two words come from a wisdom background where $s^{e} d \bar{a} q \bar{a}$ 'refers to natural wisdom based on intelligent observation and experience' and mišpa $\bar{a} t$ 'refers to regulated or disciplined observation and experience' and mišpa $\bar{t}$ 'refers to regulated or disciplined
wisdom with particular directives for the maintenance of law and order' (Wessels wisdom with 
Jehoiakim is compared in this section to his father, who is remembered as an example of a leader who lived a balanced life - he ate and drank like an ordinary person would do. But more importantly he as a leader made it his concern to see that justice prevailed in the society and, even more, he did what was right. He was the caretaker of justice, but he himself acted justly and with righteousness. Verse 16 takes the matter of justice and righteousness one step further by putting it in real terms: Josiah made it his concern that the rights of the weak and the poor were safeguarded. These were people who had no legal rights or access to legal representation (Fretheim 2002:328; Wessels 2012:181-196). In both verses 15-16 a summary statement is made about how Josiah's attitude and actions are judged by saying what he did was good $(t \bar{o} b)$. It is a judgement that expresses lifegiving potential and prosperity (Stoebe 1971:654; cf. also Dt $5: 16 ; 6: 18 ; 12: 28)$. This reminds us again of the definition of Ciulla (2004:xv) quoted in the beginning that leadership should have 'a shared vision of the good'. Leaders, in particular, should know right from wrong and take care and responsibility for what takes place in the relationship between leaders and followers. Against this benchmark set by Josiah, Jehoiakim's leadership is judged a failure and nothing less than an abuse of power. The observation is made that Josiah acted as a leader is supposed to because he 'knew' YHWH. This knowledge is born from an intimate relationship with YHWH, from where a proper understanding of his will is born. YHWH's will in this context is an understanding of the requirements of the covenant stipulations and obedience to his will. To make Jehoiakim's abuse of justice even more concrete, verse 17 states, 'But your eyes and heart are only on your dishonest gain, for shedding innocent blood, and for practicing oppression and violence' (NRSV). With these injustices in mind, it is quite understandable that the leaders are regarded as a failure. They fell from grace and should be replaced, as Jeremiah 23:1-6 suggests, by leaders who fit the requirements of being proper leaders (shepherds).

What are the major aspects that emanate from the exposition of Jeremiah 23:1-6 and related passages and the exploration and analysis of the shepherd metaphor? Leaders in the government sector, the kings and their administration, are expected to lead people and give direction to followers. It is expected of leaders to be in touch with the needs and the concerns of their subordinates. They are further expected to care for their people in the sense of taking care of their wellbeing. This would imply providing security in the sense of safety, protection and a stable and secure environment. Leaders are also responsible for providing the means for people to sustain themselves in terms of food and physical needs (pasture).

But besides these essential aspects of leadership so adequately demonstrated by the shepherd metaphor, the Jeremiah brand of shepherd leadership focuses in essence on the righteousness and justice aspects of leadership. Leaders are expected to base their leadership on ethical principles guiding their actions and decisions. For Jeremiah the covenant law code served as the basis for ethical living and decision-making (Brueggemann 1998:200). A leader should ask the question as a rule of thumb: What is fair and just in my decision-making and actions that affect and have consequences for people I lead? I agree with Ciulla (2004), who says:

The ethics of leadership - whether they be good or bad, positive or negative - affect the ethos of the workplace and thereby help to form the ethical choices and decisions of the workers in the workplace. (p. 26)

The ethical core of leaders should be well based and sound before moving to a position of demanding ethical conduct by those they lead. The shepherd leader in Jeremiah was expected to be just and fair to others, but also to safeguard these aspects in society. This leader had the responsibility to ensure that the principles of justice and righteousness are protected and applied.

\section{From text to reality}

In the discussion above on the Jeremiah texts, a number of very important matters of leadership and leadership responsibility surfaced. The question is whether these matters resonate with the thoughts and trends people attend to in business and leadership situations? It is not so difficult within religious circles to adhere to moral and ethical standards, since an appeal can be made on grounds of sacred documents such as the law code in the Old Testament or the Bible as the book of Christians. McCoy (2007:1-11) discusses what he calls 'established ethical frameworks'. He refers to normative ethics, Kantian ethics, social justice ethics, religious ethics and communitarian ethics. In Christian leadership the emphasis is on religious ethics with its acknowledgment of the divine and recognition of Christian scripture as a key ingredient in moral formation and ethical decision-making. In the secular world ethics depends on approaches such as rational models, moral philosophical arguments and natural laws (Barton 2003:45-64). There are therefore no fixed external norms one has to adhere to, but decisions are made on rational grounds in terms of what seem to make sense and convince people to be the correct option in a particular circumstance. There is, however, leadership literature in circulation that promotes similar ideas we found in the Jeremiah texts that is worth mentioning. One such source is the book by Sinclair (2007), who has highlighted the following aspects:

Responsible leadership requires a deep sense of self and community - valuing diversity, ethics, the individual and the collective. It is something that involves all of us, as leaders and followers equally, binding us in a moral relationship that can be quickly undermined through neglect or indifference. Leadership should be aimed at helping to free people from oppressive structures, practices and habits encountered in societies and institutions, as well as within the shady recesses of ourselves. Good leaders liberate. (p. xv)

It is not difficult to relate the contents of this quotation to the aspects in terms of which the shepherd leaders of Jeremiah have failed. The leaders in Judah did not value the people; in actual fact, they abused them, acted unethically by denying them their rights, used them for forced labour and offered 
no protection for those who had no legal rights. The leaders abused the moral relationship and actually oppressed the people instead of liberating them. It therefore seems a fair assumption to make that texts such as the Jeremiah ones can inform and support literature in circulation that appeals to ethics in the workplace.

What has transpired so far was a view on leadership from the religious text of Jeremiah using the shepherd metaphor. This metaphor created a mental image for the hearers and readers of the prophetic oracles to enrich their understanding of what leadership entails for Jeremiah. The question, however, remains how suitable this metaphor is for an audience today. What purpose does it serve to engage such a metaphor for leadership from a modern day perspective? It should be admitted that there are many metaphors in circulation in leadership literature that assist expressions and views on leadership. One metaphor that comes to mind is servant leadership that is often promoted as a style of leadership that can serve a well needed purpose today. The concept of servant leadership, according to Anand et al. (2011:319-320), originated with Greenleaf in 1977 and emphasises ethics, integrity and moral responsibility. A clear and engaging discussion of servant leadership worth reading is offered by Blanchard (2010:291-297). It should be admitted that a single metaphor is not exhaustive enough to express adequately all that can be said about leadership. Metaphors, however, are handy ways to communicate ideas on leadership effectively to audiences, but the context and requirements of a specific situation should help determine the choice of the metaphor. The communicator who chooses the metaphor should do that with the purpose of highlighting certain matters or to convince the audience of some aspects needed or what is absent and needs to be rectified. The author of the Jeremiah text regarded the shepherd metaphor as most suitable to address the shortcomings of the leadership of his time. As mentioned, it was a suitable metaphor that would appeal to the audience of Jeremiah's time. From an urban perspective and in a workplace setting that is far removed from such rural contexts which gave rise to the shepherd metaphor in Jeremiah's time, we should perhaps search for more suitable metaphors for our purposes. This is, however, not to say that we cannot relate to this particular metaphor, since its common use in many societal setups makes its use still relevant. What makes the Jeremiah brand of the shepherd metaphor attractive and relevant to us is the emphasis on the ethical demands on leaders to act in righteousness and to protect justice. As the shepherd had to care for the weak in the flock, so the king and his administration had responsibility to protect the weak, in particular the widows and orphans. In short, all those who have no legal rights or protection and are vulnerable are the responsibility of the shepherd-leader. These sentiments are also promoted by Delbecq (2008:487488) when he talks of spiritual intelligence and spiritually inspired leadership. One of the main points he raises is that this kind of leadership in organisations is 'attentive to the common good, justice, and the needs of the poor' (ibid:500502). Delbecq would therefore find support in the Jeremiah Shepherd metaphor for leadership to sustain his views.
The Jeremiah text forms part of the Christian canon and is therefore relevant to people who by choice engage with these texts as formative for their life context. However, even people who have no religious interest can read these texts as literature with the purpose of acquainting themselves with views expressed in them on issues of interest. As Rogerson (2001:37) remarks, '... morality and ethics are of concern to secular as well as religious interests.' The point is, the texts in Jeremiah using the shepherd metaphor communicate convictions on how leaders in key positions in society should ethically behave. That alone is enough to entice people to take note of these views and engage them. The texts in Jeremiah employing the shepherd metaphor originated in a context where concerns were raised about leaders in positions of power who violated the ethical demands of the covenant relationship. These obligations were supposed to form the framework in which the leaders operate and exercise their leadership.

It is a question whether Old Testament texts such as the ones in the book of Jeremiah are of any value in establishing ethical guidelines and ethical formation? The answer is twofold: an analysis of these texts may show particular ethical convictions being promoted that are relevant to the historical context within which they function at first. It is possible to identify these ethical convictions, to show how they appealed to people, who were the people who promoted these views and how people reacted to these ethical demands. The second part of the answer concerns later audiences and readers confronted by these ethical demands and their responses to them from new and different historical contexts. We form part of these last-mentioned audiences and readers of the Jeremiah texts. For some people who regard these texts and the image presented as having divine authority, these texts will be binding and have to be obeyed. For others who have a different view on the status of the text, it will be a matter of how the ideas presented in the texts resonate with the convictions and experiences of these people.

In a chapter entitled 'The basics of ethics in the Hebrew Bible', Barton (2003:45-54) discusses three basic models for ethics in the Hebrew Bible. This first is 'obedience to God's declared will', the second 'natural law' and the third 'imitation of God'. For people who adhere to the authority of the Bible, the obedience model is the acceptable one. For others, however, who have a strong sense of moral and ethical behaviour, but regard the biblical text not as prescriptive, the model of 'natural law' is more attractive. This latter model regards things 'the way they are' as a natural way to become aware of knowledge of God and also as what ethical behaviour entails. To my mind, it is close to what Wisdom Literature promotes in searching for 'order' and ways to be in harmony with the created order. This will probably link up with models promoting cognitive thinking systems for making ethical decisions (Bazerman \& Tenbrunsel 2011:34-37).

The argument of this article is that the ideas expressed by means of the shepherd metaphor in the book of Jeremiah make sense within that particular historical context but, more 
than that, appeal to the local and international contexts as well. Government with its leadership structures should lead like the shepherd-leaders of Jeremiah's time were supposed to by caring for the ordinary people, and by protecting them and their rights. These leaders should in the first place judge whether their own leadership meets the standards of righteousness and justice. They should, however, also take care that the leadership structures they put in place and have responsibility for comply with the ethical standard of what is considered fair and just. It is their responsibility to oversee that all that shepherd-leadership entails trickles down to every leadership structure in the workplace. If this is required for leadership in general, the more it will apply to Christian leaders in government, but also to every other workplace setting.

\section{Conclusion}

The texts observed in the book of Jeremiah have clearly indicated what is expected of leaders, but have also shown that leaders are accountable. In the case of Jeremiah, leaders were accountable first to $\mathrm{YHWH}$, but also to the people whom they were supposed to lead. With leadership comes responsibility and accountability. This accountability concerns general leadership and the well-being of people, but is more specific in terms of justice and righteousness. To this can be added that the Jeremiah text has also highlighted the negative consequences that follow on leadership in violation of justice and righteousness. Failed leadership in terms of the shepherd metaphor has far-reaching consequences for the leaders themselves, but also for the followers.

The shepherd metaphor in Jeremiah seems relevant to Christian leaders in our local context in the sense that it has not only emphasised 'the leading of people' aspect, but also the moral obligation of leaders. The sections discussed in Jeremiah mainly concerned the kings and their administration, but readers of these texts are confronted within their own leadership contexts in the workplace with the issues of justice and righteousness. Leaders have to account for their ethical conduct and the effects of their conduct on ordinary people. Christian leaders can play a crucial role in the workplace by caring for the relational aspects of work and business. Christian leadership should cultivate 'the deep sense of the other', born out of deep religious convictions. This will enable them to live out their religious beliefs. It will benefit them but also others who form part of their relationships (McCoy 2007:10-11). The workplace is all about production and profit, often insensitive towards people's well-being and wellness. Christian leaders can bring the realisation that 'organizational, managerial, and leadership decisions are inevitably coloured by morality and ethical consequences' (Bolden et al. 2011:153).

\section{Acknowledgements Competing interests}

The author declares that he has no financial or personal relationship(s) that may have inappropriately influenced him in writing this article.

\section{References}

Allen, L.C., 2008, Jeremiah: A commentary, Westminster John Knox, Louisville.

Anand, S., Hu, J., Liden, R.C. \& Vidyarthi, P.R., 2011, 'Leader-member exchange: Recent research findings and prospects for the future', in A. Bryman, D. Collinson, K. Grint, B. Jackson \& M. Uhl-Bien (eds.), The Sage handbook of leadership, pp. 311-322, SAGE Publications, London.

Barton, J., 2003, Understanding Old Testament ethics, Westminster John Knox, London.

Bazerman, M.H. \& Tenbrunsel, A.E., 2011, Blind spots: Why we fail to do what's right and what to do about it, Princeton University Press, Princeton.

Blanchard, K., 2010, 'Leadership ethics and integrity for the 21st century', in E. Biech (ed.), The ASTD leadership handbook, pp. 291-297, ASTD Press, Alexandria. PMid:20861151

Bolden, R., Hawkins, B., Gosling, J. \& Taylor, S., 2011, Exploring leadership: Individual, organizational \& societal perspectives. Oxford University Press, Oxford.

Brueggemann, W., 1998, A commentary on Jeremiah: Exile and homecoming, Eerdmans, Grand Rapids.

Carroll, R.P., 1986, Jeremiah: A commentary, SCM, London.

Ciulla, J.B. (ed.), 2004, Ethics, the heart of leadership, Praeger Publishers, Westport. PMCid:PMC543466

Craigie, P.C., Page, H. \& Drinkard, J.F. Jr., 1991, Jeremiah 1-25, Word Book Publishers, Dallas, Texas.

Delbecq, A.L., 2008, 'Nourishing the soul of the leader. Inner growth matters', in J.V. Gallos (ed.), Business leadership: A Jossey-Bass reader, pp. 486-503, John Wiley $\&$ Sons, San Francisco.

Dewe, P. \& Cooper, G., 2012, Well-being and work: Towards a balanced agenda, Palgrave Macmillan, Basingstoke, Hampshire. http://dx.doi.org/10.1057/9780230363038

DuBrin, A.J., 2013, Principles of leadership, 7th international edn., Nelson Education, Canada.

Fischer, G., 2005, Jeremia 1-25. Ubersetzt und ausgelegt, Herder, Freiburg.

Fretheim, T.E., 2002, Jeremiah, Smyth \& Helwys, Macon.

Jindo, J.Y., 2010, Biblical metaphor reconsidered: A cognitive approach to poetic prophecy in Jeremiah 1-24, Harvard Semitic Museum Publications, Boston.

Lundbom, J.R., 2004, Jeremiah 21-36: A new translation with introduction and commentary, Doubleday, New York.

McCoy, B.H., 2007, Living into leadership: A journey in ethics, Stanford University Press, Stanford.

McKane, W., 1986, A critical and exegetical commentary on Jeremiah I-XXV, T\&T Clark, Edinburgh.

O'Brien, J.M., 2008, Challenging prophetic metaphor: Theology and ideology in the prophets, Westminster John Knox, Louisville.

Rogerson, J., 2001, 'The Old Testament and Christian ethics', in R. Gill (ed.), The Cambridge companion to Christian ethics, pp. 29-41, Cambridge University Press, Cambridge.

Rudolph, W., 1968, Jeremia, 3rd rev. edn., J.C.B. Mohr, Tübingen.

Sinclair, A., 2007, Leadership for the disillusioned: Moving beyond myths and heroes to leading that liberates, Allen \& Unwin, Sydney.

Stoebe, H.J., 1971, s.v. 'țōb', in E. Jenni \& C. Westerman (eds.), THAT, band 1, bl. $654-$ 664 , Chr. Kaiser Verlag, München.

Sweeney, M.A., 2007, 'Jeremiah's reflection on the Isaian royal promise: Jeremiah 23:1-8 in context', in J. Goldingay (ed.), Uprooting and planting: Essays on Jeremiah for Leslie Allen, pp. 308-321, T\&T Clark, New York.

Thompson, J.A., 1980, The book of Jeremiah, Eerdmans, Grand Rapids.

Wessels, W.J., 1994, 'A theology of renewal: A perspective on social justice from the book of Jeremiah', in M. Wilson (ed.), Spirit and renewal: Essays in honor of J. Rodman Williams, pp. 93-109, Sheffield Academic Press, Sheffield.

Wessels, W.J., 2012, 'Prophet and ethics: A study of Jeremiah 5:26-29', in D. Human (ed.), Psalmody and poetry in Old Testament ethics, pp. 181-196, T\&T Clark, London. 